\title{
Counseling Needs for the Female Students of Prince Sattam bin Abdulaziz University (A Field Study on Students of the Faculty of Education in Ad Dilam)
}

\author{
Dr. Nahla Mohammed Awad Al-Qur'an \\ Jadara University- Jordan
}

\begin{abstract}
The purpose of this study aims at identifying the most important counselling needs of female students of the Faculty of Education in Ad Dilam, affiliated to Prince Sattam bin Abdulaziz University, and identifying the differences between the counseling needs according to the variables: specialization, social status and place of residence. To achieve the objectives of the study, the researcher prepared an instrument to measure the counseling needs, consisting of (40) paragraphs distributed over (4) areas: psychological, professional, social and academic. Moreover, the scale was applied to a sample of (325) students randomly selected from the students of the Faculty of Education. After the statistical analysis of the data, the results of the study showed that the psychological were the most important of these needs, followed by the social, the academic and finally the professional needs. The results also showed no significant differences between the married and unmarried students, the academic specialization and the place of residence.
\end{abstract}

Key Terms: Counseling Needs, Prince Sattam University.

DOI: $10.7176 / \mathrm{JEP} / 11-20-08$

Publication date:July $31^{\text {st }} 2020$

\section{Introduction}

Undergraduate is considered one of the most significant stages in which individuals go through and the most influential in their direction. Moreover, counseling services represent the most essential requirements that must be provided to the university student. The counseling needs are the most important educational issues that have received great attention from specialists in this field. This is due to their particular importance in helping the students to satisfy their needs, attain their healthy psychological compatibility and refining their aptitudes and abilities to reach the maximum degree of adaptation and compatibility; as "it constitutes the core part of the individual's psychological formation because it affects his personality and drives him to behavior that leads to his satisfaction or gratification; he lives most of his life in order to satisfy his needs, reduce his tensions and achieve his goals," (Alzibadei and Alkhatib, 2000, p. 44). The need to study the counseling needs of the university students in our contemporary age; the era of speed, globalization and constant change has been increased. Thus leading to the occurrence of many conflicts within the individual's self, thereby placing him in front of multiple needs that he must always strive to satisfy them so as not to become an easy prey and prone to many problems.

\section{Study Problem}

The preparation for this stage requires identifying the students' needs in order to satisfy them. However, since the researcher has been working as an Assistant Professor at the Faculty of Education in Ad Dilam, Head of the Guidance and Counseling Unit at the Prince Sattam University and through her meeting with many female students in the various branches of the university in its six governorates, she noted that female college students suffer from many problems in various fields. Hence, in order to contribute to solving this problem, we must identify the problems of the student and her counselling needs, so that we can provide a healthy psychological, educational and social environment in which she can adapt to the different and renewable conditions of life. Consequently, this study came to identify the counselling needs of the students of the Faculty of Education in Ad Dilam because of the absence of previous studies conducted on the students of Prince Sattam University in general and the students of the Faculty of Education in Ad Dilam in particular. The problem of the study attempts to answer the following questions:

- What are the students' counseling needs of the College of Education at the Prince Sattam bin Abdul Aziz University?

- Are there statistically significant differences $(\alpha=0.05)$ between the average grade of students on the scale of the counseling needs due to the social situation variable?

- Are there statistically significant differences $(\alpha=0.05)$ between the average grade of students on the scale of counseling needs due to the residence location variable? 
- Are there statistically significant differences $((\alpha=0.05)$ between the average grade of students on the scale of counseling needs due to the study major variable?

- What are the educational recommendations that will contribute to satisfying the needs of the university girl?

\section{Study Objectives}

- Identifying the most important academic, social, psychological and professional needs of the students of the Faculty of Education in Ad Dilam and identifying them in terms of priority and importance.

- Developing an instrument to measure the counseling needs of the female university students.

\section{Study Significance}

The nature of the age and educational stage of the female university student and the need to learn her counseling needs and work requirements in order to address and mitigate the effects on the student and society, thereby improving her adaptation to university level. This study also examines the counseling needs of the students at the Prince Sattam University for the first time and therefore provides a set of recommendations for the staff in the Student Affairs in order to develop preventive, therapeutic and developmental counseling programs that contribute to the achievement of the objectives of university counseling.

\section{Procedural Definitions}

Counseling Needs: These are the needs that the female university students see as necessary to help them solve their problems. In the light of the current study, they are divided into four areas, in which the students see that it is necessary to be met during the university duration. These areas are: academic, professional, social and psychological. They are inferred through the scale of counseling needs prepared for this study.

\section{Study Limits}

- The study sample is limited to female students of the Faculty of Education in Ad Dilam for the second semester of the academic year 1438/1439 $\mathrm{H}$

- The study is limited to the questionnaire as a data collection instrument. Therefore, the results of this study are determined by the validity and reliability of the study instrument.

\section{Review of Literature}

The counseling and guidance process was found since the presence of mankind, it was used with our master Adam, peace be upon him, so God guided him how to enter Paradise and what he has to do. We said: "O Adam! Dwell thou and thy wife in the Garden; and eat of the bountiful things therein as (where and when) ye will; but approach not this tree, or ye run into harm and transgression.” (35) Al-Baqara.

In addition, our Prophet Muhammad (peace and blessings of Allah be upon him) pointed out the counseling in many situations during his honorable life and traditions. The counseling and guidance today is an organized discipline that has its own theories, principles and concepts. Many theories have addressed the issue of human needs due to the significance of this issue in achieving proper compatibility. One of these theories and the most important is the theory of Maslow, which arranged the needs of humans in accordance with a hierarchy starting from the lowest then the higher and the highest. He considered that "mankind has the option of free will in deciding his own destiny and he is in a continuous movement forward, seeking to get rid of all the obstacles to satisfy his needs". (Gilbert, 1997).

"Rogers, however believes that the basic need is the need for self-actualization and the pursuit of perfection, that the individual has tendencies to move forward and that self-actualization is a major need that mankind seeks to satisfy so that he can continue to adapt positively with others and with himself" (Thompson \& Rudolph, 1992: p44). While Freud looked at human nature pessimistically and saw that mankind's main motivation is to satisfy his physical and sexual needs, thereby his behavior is governed by the principle of pleasure.

Since the female student is the focus of the educational process, looking at her different needs is the key to her success. "Therefore, meeting the needs of the female university student is an essential requirement in the field of university counseling and is considered one of the most significant objectives of the world's universities" (Collins \& Pieters, 2007). Moreover, building a personality that will be able to take responsibility one day has become very complex task in the current era, in which there is a great deal of influences surrounding the female student, and therefore it is necessary to deal with students, and with ourselves, from a new perspective that is different from the above." (Grenchik, O'Conner \& Postelli, 1999 p 22).

\section{Previous Studies}

Some studies that have been used in the current research: 
- Al-Smadi and Al-Tahan (1996) had studied the counseling needs of United Arab Emirates University students.

- (Wainwright et al., 1998) conducted a follow-up study on newly counseled of the university counseling services.

- While Al Musharaf (2000) studied the problems of the students of Sana'a University and their counseling needs,

- The study conducted by Al-Tahan and Abu Aita (2002), aimed at evaluating the counseling needs of the Hashemite University students,

- The study conducted by (2008) (p. 89 Study of the needs of the Sultanate of Oman) under the title "Assessment of the counseling needs of students graduates of Nigerian universities."

- In the study of Nuri and Yehia (2008), which aimed to identify the psychological and social counseling needs of the students of Mosul University,

- In the study of Rizq (2008), which aimed at identifying the counseling needs of high school students according to different fields (scholastic, personal, emotional, family, and social),

- Al-Hakmani (2008) studied the counseling needs from the point of view of the students of private universities in the Sultanate of Oman.

- In Al-Jubouri study (2011), which aimed to identify the counseling needs of the students of the Faculty of Physical Education at the University of Babylon,

- In the study of Tashtoosh (2012), which aimed to identify the counseling needs of the preparatory year students in Qasseem University.

- In the study of Ramadan (2013), which aimed to reveal the counseling needs of students of the Faculty of Education and its relationship to gender and scientific specialization.

- In the study carried out by Al-Sawiya (2013), which aimed at uncovering the counseling needs of the students of the Faculty of Education at Princess Noura Bint Abdulrahman University in the academic, psychological and social fields and their relationship with the academic .

- In the study carried out by Abu Al-Aish (2014) aimed at identifying the most important counseling needs for the students of the Faculty of Education at the University of Hail,

- In the study of Ramadan and Sarhan (2016), which aimed to identify the level of counseling needs and academic aspirations in general and according to the housing variable among students of the University of Kirkuk,

- It is clear from the previous presentation that most of the previous studies addressed the counseling needs at the level of university students.

\section{Study Population and its Sample}

The study population consists of all female students enrolled in the second semester 2017/2018 for the first, second, third and fourth years in the Faculty of Education in Ad-Dilam. The total number of female students is (1714) divided into five majors: Islamic Studies (714), Arabic Language (583), Home Economics (241), Mathematics (164), and Chemistry (12) students, according to the statistics of the Office of Admission and Registration in the College. As for the sample of the study, it was randomly selected, and the sample was (325) students. 
Table (1) Repetition and ratio according to the study variables

\begin{tabular}{|c|l|c|c|}
\hline Variable & \multicolumn{1}{|c|}{ Categories } & Repetition & Ratio \\
\hline \multirow{3}{*}{ Specialization } & Mathematics & 43 & 13.2 \\
\cline { 2 - 4 } & Islamic studies & 111 & 34.2 \\
\cline { 2 - 4 } & Economy & 68 & 20.9 \\
\cline { 2 - 4 } & Arabic Language & 103 & 31.7 \\
\hline \multirow{5}{*}{ Study Level } & First or Second & 101 & 31.1 \\
\cline { 2 - 4 } & Third or Fourth & 86 & 26.5 \\
\cline { 2 - 4 } & Fifth or Sixth & 126 & 38.8 \\
\cline { 2 - 4 } & Seventh or Eighth & 12 & 3.7 \\
\hline \multirow{5}{*}{ Marital Status } & Married & 64 & 19.7 \\
\cline { 2 - 4 } & Unmarried & 261 & 80.3 \\
\hline \multirow{2}{*}{ Residence Location } & Riyadh & 33 & 10.2 \\
\cline { 2 - 4 } & Al Kharj & 217 & 66.8 \\
\cline { 2 - 4 } & Ad Dilam & 75 & 23.1 \\
\hline & Total & $\mathbf{3 2 5}$ & $\mathbf{1 0 0 . 0}$ \\
\hline
\end{tabular}

\section{Survey Instrument}

The researcher developed the counseling needs questionnaire through reviewing many of the previous studies (which appeared in the Review of Literature item of the study). In light of that, the study measure should be (40) items distributed on four areas as follows:

- First area: academic needs and measurement (10) items.

- Second area: social needs and measurement (10) items.

- Third area: psychological needs and measurement (10) items.

- Fourth area: professional needs and measurement (10) items.

\section{Statistical Standard}

The Likert Fifth Point Scale was adopted to grade the study instruments, giving each item the one point of the five points (Agree Strongly, Agree, Neutral, Disagree, Disagree Strongly) and represent digitally $(5,4,3,2,1)$ respectively. The following scale was adopted for the purposes of results analysis:

From 1.00 - 2. Slight, From 2.34 - 3.67 Medium, From 3.68 - 5.00 Substantial.. etc.

Measurement was calculated by using the following equation:

Upper limit of scale (5) - Minimum scale (1) $\quad=\quad \underline{5-1}=\quad=\quad 1.33$

Number of the required categories (3)

$$
3
$$

Then adding the answer (1.33) to the end of each category.

\section{Instrument Reliability}

To ensure the instrument reliability, the test-retest method was checked by applying the scale, and re-applying it after two weeks to a group outside the study sample consisting of (40) female students, and then the Pearson correlation coefficient was calculated between their estimates in both times.

The reliability coefficient was also calculated by the method of internal consistency according to the Cronbach alpha equation, and Table (2) shows that.

Table (2) Coefficient of the internal consistency of the Cronbach alpha, the reliability of the areas retest and the overall grade

\begin{tabular}{|c|c|c|}
\hline Areas & Test-Retest Reliability & Internal Consistency \\
\hline Psychological needs & 0.87 & 0.90 \\
\hline Social needs & 0.89 & 0.84 \\
\hline Academic needs & 0.91 & 0.88 \\
\hline Professional needs & 0.92 & 0.89 \\
\hline Needs as a whole & 0.94 & 0.93 \\
\hline
\end{tabular}

Study Results and Discussion:

First Question: What are the counseling needs of female students of the College of Education in Ad Dilam in the psychological, social, academic and professional areas? To answer this question, arithmetic means and 
standard deviations for counseling needs have been extracted among female students of the College of Education in Ad Dilam in the psychological, social, academic and professional areas. The table below shows that.

Table (3) Arithmetic means, standard deviations, rank and score of estimation for each area of the instrument and the instrument as a whole:

\begin{tabular}{|c|c|c|c|c|c|}
\hline Rank & No. & Area & Arithmetic Mean & Standard Deviation & Grade \\
\hline 1 & 1 & Psychological needs & 3.74 & 1.031 & Substantial \\
\hline 2 & 4 & Professional needs & 3.54 & .875 & Medium \\
\hline 3 & 3 & Academic needs & $3: 37$ & .907 & Medium \\
\hline 4 & 2 & Social needs & 2.99 & .844 & Medium \\
\hline & & Needs as a whole & 3.41 & .693 & Medium \\
\hline
\end{tabular}

Table (3) shows that the arithmetic means ranged between (2.99 - 3.74), where psychological needs came first with the highest arithmetic mean of (3.74), while social needs came in the last rank with an arithmetic mean of (2.99), and the arithmetic mean for needs as a whole (3.41). This result indicates the importance of meeting the counseling needs of female students of Prince Sattam University. Moreover, this is consistent with what has been indicated by many previous studies, such as studies: (Al-Smadi and Tahan, 1996; Wainwright et al., AlMusharraf, 2000; Al-Tahan and Abu Aita, 2002; Guneri, Aydin , \& Skovholt, 2003; Nuri and Yahya, 2008; Rizk, 2008; Al-Barakat and Al-Hakmani, 2014; Al-Jubouri, 2011; Toshtoush, 2012; Ramadan, 2013; Abu Al-Aish, 2014; Ramadan and Sarhan, 2016). They all emphasized the need to take into account the student's counseling needs in order to be able to solve their problems and face the pressures that they face in their scientific and practical lives.

For an in-depth analysis of the study data, arithmetic means and standard deviations for the estimates of the study sample individuals were calculated on the items of each area separately, as they were as follows:

First: Psychological Needs: This area includes (10) items, each item describes the degree of female students' assessments of their psychological counseling needs. Therefore, mathematical means and standard deviations have been calculated, and Table (4) presents them in a descending order:

Table (4) Arithmetic means and standard deviations for female students' estimates of counseling needs in the psychological area

\begin{tabular}{|c|c|c|c|c|c|}
\hline Rank & No. & Area & $\begin{array}{c}\text { Arithmetic } \\
\text { Mean }\end{array}$ & $\begin{array}{l}\text { Standard } \\
\text { Deviation }\end{array}$ & Grade \\
\hline 1 & 6 & $\begin{array}{l}\text { Having a Psychological counselor in the college to } \\
\text { help me with psychological, academic, family } \\
\text { compatibility, and compatibility in general. }\end{array}$ & 3.86 & 1.180 & Substantial \\
\hline 2 & 10 & Eliminate hesitation when making my decisions. & 3.80 & 1,299 & Substantial \\
\hline 3 & 3 & Gain decision-making skill. & 3.77 & 1.240 & Substantial \\
\hline 4 & 4 & $\begin{array}{l}\text { Determine my personal goals and how to achieve } \\
\text { them }\end{array}$ & 3.76 & 1.207 & Substantial \\
\hline 4 & 5 & $\begin{array}{l}\text { Identify weak characters in my personality and } \\
\text { ways to strengthen them. }\end{array}$ & 3.76 & 1.230 & Substantial \\
\hline 4 & 7 & The ability to maintain a balanced mood. & 3.76 & 1.237 & Substantial \\
\hline 4 & 9 & Get rid of feeling anxious from the future. & 3.76 & 1.337 & Substantial \\
\hline 8 & 1 & Achieve self-confidence and self-esteem. & 3.75 & 1.382 & Substantial \\
\hline 9 & 2 & Ability to exercise self-control and behavior. & 3.63 & 1.403 & Medium \\
\hline \multirow[t]{2}{*}{10} & 8 & The ability to diagnose personal problems. & $3: 55$ & 1.361 & Medium \\
\hline & & Psychological needs. & 3.74 & 1.031 & Substantial \\
\hline
\end{tabular}

Table (4) shows that the arithmetic means ranged between (3.55 - 3.86), as Item No. (6) Stated, "Having a psychological counselor in the college to help me with psychological, academic, and family compatibility, and compatibility in general" in the first rank with an average score of (3.86), while Item (8) which reads "The ability to diagnose personal problems" came in the last rank with an average arithmetic mean of (3.55). The mean of psychological needs as a whole was (3.74). Here it shows the necessity of having a specialized psychological counselor with the highest estimate in this area as a very necessary. This is what the researcher observed through her work as a Head of the Counseling and Guidance Unit at Prince Sattam University; most of the university faculties lack the presence of a specialized and full-time psychological counselor. Moreover, the psychological needs obtaining the highest levels of estimate in general indicates the importance of achieving proper psychological growth among university students. Hence, due to the nature of the stage of development that the university student is going through, we need to consider the psychological aspects of the student, understand and analyze it and understand its causes, symptoms and methods of treatment. The results of this study are consistent with studies of: (Egbochuka, E \& Akpan, M., 2008; Al-Hakmani, 2008; Nuri and Yahya, 2008; Al-Juburi, 2011; Ramadan, 2013) in the area of attention to the psychological needs of the university 
student in order to show their energies and potentials with the purpose of developing their creativity skills. Whereas, it differed with the study of Al-Tahan and Abu Aita (2002), which showed the need for a professional and academic area more than a psychological one. It also differed with the study of (Wainwright et al, 1998), which confirmed that most students seek academic advisory services; and the study of Tashtoosh (2012), whose results showed the need for academic and professional counseling more than the need for psychological counseling.

Second: Social Needs: This field includes (10) items. Each item describes the degree of female students' estimates of their social counseling needs. Therefore, arithmetic means and standard deviations have been calculated, and Table (5) presents the items in descending order:

Table (5) Arithmetic means and standard deviations of the female students' estimates of the counseling needs in the social area

\begin{tabular}{|c|c|l|c|c|c|}
\hline Rank & No. & \multicolumn{1}{|c|}{ Area } & $\begin{array}{c}\text { Arithmetic } \\
\text { Mean }\end{array}$ & $\begin{array}{c}\text { Standard } \\
\text { Deviation }\end{array}$ & Grade \\
\hline 1 & 18 & Gaining the courage to claim special rights. & 3.14 & 1.303 & Medium \\
\hline 2 & 12 & $\begin{array}{l}\text { Eliminate confusion when I speak in front of } \\
\text { others. }\end{array}$ & 3.10 & 1.318 & Medium \\
\hline 3 & 11 & Get rid of feeling shy when faced with others. & 3.06 & 1.359 & Medium \\
\hline 3 & 17 & Gain the skill of persuading others. & 3.06 & 1.218 & Medium \\
\hline 5 & 14 & $\begin{array}{l}\text { Develop my abilities to form positive } \\
\text { relationships with my colleagues. }\end{array}$ & 3.02 & 1.337 & Medium \\
\hline 6 & 15 & $\begin{array}{l}\text { The ability to adapt to the social environment } \\
\text { surrounding me. }\end{array}$ & 3.00 & 1.229 & Medium \\
\hline 7 & 19 & Negotiation skills with others. & 2.93 & 1.250 & Medium \\
\hline 8 & 20 & $\begin{array}{l}\text { Participation in social activities within the } \\
\text { college. }\end{array}$ & 2.91 & 1.336 & Medium \\
\hline 9 & 16 & Ability to come to terms with others. & 2.99 & 1.360 & Medium \\
\hline 10 & 13 & Accept others' criticism of me. & \multicolumn{1}{|c|}{ Medium } \\
\hline & & Social Needs & Medium \\
\hline
\end{tabular}

Table (5) shows that the arithmetic means ranged between (2.84 - 3.14), which means that all of the items were distributed within a medium estimate score. Item (18) stating that "Gaining the courage to claim special rights" came first and with an arithmetic mean of (3.14), while item (13) that reads "Accept others' criticism of me "came in the last rank, with an average score of (2.84). The mean for the social needs as a whole was (2.99). Hence, it appears to us that there are needs to provide social services to help female students to adapt to the university environment; to develop the student's social skills, such as communication skills in order to get rid of excess shyness when meeting others; to gain the skill of persuasion and accepting criticism from others; the ability to come to terms with others, and the need to participate in social activities within the college. This result is consistent with the results of many previous studies, such as (Al-Jubouri, 2011; Ramadan, 2013; Abu Al-Aish, 2014); while its results differed with the study of Al-Samadi and Tahhan, 1996; the Al-Musharraf study, 2000; the study of Al-Tahhan and Abu Aita, 2002; the study of Nuri and Yahya, 2008; the study of Barakat and AlHakmani, 2014; in which they all showed that the needs of students in the social area were the lowest of these needs.

Third: Academic Needs: This field includes (10) items, each item describes the degree of female students' estimates of their academic counselling needs. Therefore, mathematical means and standard deviations have been calculated, and Table (6) presents the items in descending order: 
Table (6) Arithmetic means and standard deviations of female students' estimates of their counselling needs in the academic area

\begin{tabular}{|c|c|c|c|c|c|}
\hline Rank & No. & Area & $\begin{array}{l}\text { Arithmetic } \\
\text { Mean }\end{array}$ & $\begin{array}{l}\text { Standard } \\
\text { Deviation }\end{array}$ & Grade \\
\hline 1 & 29 & $\begin{array}{l}\text { Methods to help raise the average and academic } \\
\text { excellence. }\end{array}$ & 3.65 & 1.253 & Medium \\
\hline 2 & 23 & $\begin{array}{l}\text { Eliminate the anxiety that accompanies the } \\
\text { exams. }\end{array}$ & 3.50 & 1.295 & Medium \\
\hline 3 & 22 & $\begin{array}{l}\text { Get rid of some negative attitudes towards some } \\
\text { courses. }\end{array}$ & $3: 49$ & 1.206 & Medium \\
\hline 4 & 26 & How to organize study and activity time. & 3.43 & 1.300 & Medium \\
\hline 5 & 27 & Gain the skill to answer exam questions. & $3: 42$ & 1.295 & Medium \\
\hline 6 & 21 & Learn the best methods of studying & 3.41 & 1.371 & Medium \\
\hline 7 & 30 & $\begin{array}{l}\text { The ability to deal with problems so that my } \\
\text { college life is not affected. }\end{array}$ & $3: 35$ & 1,312 & Medium \\
\hline 8 & 24 & Developing motivation for self-study. & $3: 28$ & 1.226 & Medium \\
\hline 9 & 25 & Overcoming failure in some courses. & 3.18 & 1.439 & Medium \\
\hline 10 & 28 & Computer skill acquisition. & 3.02 & 1.345 & Medium \\
\hline & & Academic needs & $3: 37$ & .907 & Medium \\
\hline
\end{tabular}

Table (6) shows that the arithmetic means ranged between (3.02 - 3.65), this means that they were distributed within a medium estimation score, as item (29) which states "Methods to help raise the average and academic excellence" came first and with an arithmetic mean of (3.65), while Item No. (28) stating, "Computer Skills Acquisition", ranked last, with an average score of (3.02). Hence, it appears to us that the female students' estimates of their counseling needs at Sattam University on the academic area were significant, as the mean for the academic needs as a whole was (3.37). This result reflects to us the importance of having centers and counseling units for female students at the university to help female students get rid of the fear that accompanies the tests, get rid of some negative attitudes toward some study courses, how to organize study time and acquire the skill to answer exam questions, learn the methods of studying and develop the motivation to study. The researcher believes that the universities' observance of these needs will contribute to making the student able to develop her personality and capabilities in an integrated way to become more aware and conscious of making her decisions in the academic field based on her capabilities and competences. This study agrees in this area with the studies: (Guneri, Aydin, \& Skovholt, 2003; Wainwright et al, 1998; Al-Mushrif, 2000; Al-Tahhan and Abu Aita, 2002; Nuri and Yahya, 2008; Barakat and Al-Hakmani, 2014; Toshtoush, 2012; Al-Jubouri, 2011; Al-Saqiyyah, 2013; Ramadan And Sarhan, 2016). They all showed the students' need for the academic area more than the need for other areas. This study also differed with the study of Ramadan, 2013, which showed the need for the academic area less than the need for other areas.

Fourth: Professional needs

Table (7) Arithmetic means and standard deviations of female students' estimates of their counselling needs in the professional area

\begin{tabular}{|c|c|l|c|c|c|}
\hline Rank & No. & \multicolumn{1}{|c|}{ Area } & $\begin{array}{c}\text { Arithmetic } \\
\text { Mean }\end{array}$ & $\begin{array}{c}\text { Standard } \\
\text { Deviation }\end{array}$ & Grade \\
\hline 1 & 32 & How to perform a successful interview to get a job. & 3.82 & 1.241 & Substantial \\
\hline 2 & 31 & $\begin{array}{l}\text { Guide me on job opportunities available after } \\
\text { graduating from university. }\end{array}$ & 3.78 & 1,222 & Substantial \\
\hline 3 & 33 & Determine the profession that suits me. & 3.70 & 1.292 & Substantial \\
\hline 4 & 39 & $\begin{array}{l}\text { Knowing how to present myself (in CV and job } \\
\text { interview) }\end{array}$ & 3.60 & 1.197 & Medium \\
\hline 5 & 38 & Learn about sound methods in financial management. & 3.51 & 1.234 & Medium \\
\hline 6 & 35 & Obtaining information on different professions. & $3: 42$ & 1,200 & Medium \\
\hline 6 & 37 & $\begin{array}{l}\text { How to match my capabilities with the occupations } \\
\text { available in the labor market. }\end{array}$ & $3: 42$ & 1.151 & Medium \\
\hline 8 & 34 & Learn to write a CV. & $3: 40$ & 1.296 & Medium \\
\hline 8 & 36 & Learn professional decision-making skills. & $3: 40$ & 1.192 & Medium \\
\hline 10 & 40 & $\begin{array}{l}\text { Knowledge of the art and skills of dealing with female } \\
\text { colleagues and my boss at work }\end{array}$ & 3.34 & 1.306 & Medium \\
\hline & & Professional needs & 3.54 & .875 & Medium \\
\hline
\end{tabular}

Table (7) shows that the highest arithmetic mean were for item (32) which states "How to perform a 
successful interview to get a job" and with an average of (2.32). Whereas item (40) which states "Knowledge of the art and skills of dealing with female colleagues and my boss at work", last rank, with a mean score of (3.34). The mean of the professional needs as a whole was (3.54). This result is similar to the findings of $A b u A l-A i s h$, 2014; Toshtoush, 2012; Guneri, Aydin, \& Skovholt, 2003, which all showed the need for the professional side, while it differed with the Nuri and Yahya study, 2008 and the Al-Musharraf study, 2000, in which the need for the professional area emerged as the lowest of these needs.

Second Question: Are there statistically significant differences between the average scores of female students on the scale of counseling needs attributable to the variable of marital status?

To answer this question, the researcher extracted the arithmetic mean and the standard deviations of the female students' scores on the counseling needs scale according to the marital status variable. To show the statistical differences between the arithmetic averages, the "T" test was used, and the tables below show that.

Table (8) Arithmetic means, standard deviations, and " $T$ " test for the impact of the marital status on female students' scores on the counseling needs scale attributable to the marital status variable

\begin{tabular}{|c|c|c|c|c|c|c|c|}
\hline & $\begin{array}{l}\text { Social } \\
\text { Status }\end{array}$ & No. & $\begin{array}{c}\text { Arithmetic } \\
\text { mean }\end{array}$ & $\begin{array}{l}\text { Standard } \\
\text { Deviation }\end{array}$ & $\begin{array}{l}\text { "T" } \\
\text { Value }\end{array}$ & $\begin{array}{c}\text { Degrees of } \\
\text { Freedom }\end{array}$ & $\begin{array}{c}\text { Statistical } \\
\text { Significance }\end{array}$ \\
\hline \multirow{2}{*}{$\begin{array}{l}\text { Psychological } \\
\text { Needs }\end{array}$} & Married & 64 & 3.75 & 1.079 & \multirow[t]{2}{*}{.135} & \multirow[t]{2}{*}{323} & \multirow[t]{2}{*}{.893} \\
\hline & Unmarried & 261 & 3.74 & 1.021 & & & \\
\hline \multirow[t]{2}{*}{ Social Needs } & Married & 64 & 3.16 & .908 & \multirow[t]{2}{*}{1,794} & \multirow[t]{2}{*}{323} & \multirow[t]{2}{*}{.074} \\
\hline & Unmarried & 261 & 2.95 & .824 & & & \\
\hline \multirow{2}{*}{$\begin{array}{l}\text { Academic } \\
\text { Needs }\end{array}$} & Married & 64 & $3: 35$ & .910 & \multirow[t]{2}{*}{-.186} & \multirow[t]{2}{*}{323} & \multirow[t]{2}{*}{.853} \\
\hline & Unmarried & 261 & $3: 38$ & .908 & & & \\
\hline \multirow{2}{*}{$\begin{array}{l}\text { Professional } \\
\text { Needs }\end{array}$} & Married & 64 & 3.59 & .810 & \multirow[t]{2}{*}{.541} & \multirow[t]{2}{*}{323} & \multirow[t]{2}{*}{.589} \\
\hline & Unmarried & 261 & 3.52 & .891 & & & \\
\hline \multirow{2}{*}{$\begin{array}{lll}\text { Needs as a } \\
\text { whole }\end{array}$} & Married & 64 & 3.46 & .742 & \multirow[t]{2}{*}{.704} & \multirow[t]{2}{*}{323} & \multirow[t]{2}{*}{.482} \\
\hline & Unmarried & 261 & $3: 40$ & .682 & & & \\
\hline
\end{tabular}

From Table (8), it is clear that there are no statistically significant differences $(=0.05)$ due to the impact of the social status in all areas and in the overall score.

Third Question: Are there statistically significant differences between the average scores of female students on the scale of counseling needs attributable to the variable of the place of residence?

To answer this question, the mean and standard deviations for female students scores were extracted on the counseling needs scale according to the place of residence variable, and the table below shows that.

Table (9) Arithmetic means and standard deviations for female students' scores on the counseling needs scale according to the place of residence variable

\begin{tabular}{|l|l|c|c|c|}
\hline & \multicolumn{1}{|c|}{ Categories } & No. & Arithmetic mean & Standard Deviation \\
\hline Psychological Needs & Riyadh & 33 & 3.66 & 1.167 \\
\cline { 2 - 5 } & Al Kharj & 217 & 3.79 & 1.010 \\
\cline { 2 - 5 } & Ad Dilam & 75 & 3.63 & 1.033 \\
\cline { 2 - 5 } & Total & 325 & 3.74 & 1.031 \\
\hline \multirow{5}{*}{ Academic Needs } & Riyadh & 33 & 3.00 & 1.035 \\
\cline { 2 - 5 } & Al Kharj & 217 & 3.01 & .861 \\
\cline { 2 - 5 } & Ad Dilam & 75 & 2.93 & .697 \\
\cline { 2 - 5 } & Total & 325 & 2.99 & .844 \\
\hline \multirow{5}{*}{ Needs as a whole } & Riyadh & 33 & 3.40 & 1.003 \\
\cline { 2 - 5 } & Al Kharj & 217 & $3: 40$ & .917 \\
\cline { 2 - 5 } & Ad Dilam & 75 & $3: 28$ & .837 \\
\cline { 2 - 5 } & Total & 325 & $3: 37$ & .907 \\
\hline Social Needs & Riyadh & 33 & 3.60 & .843 \\
\cline { 2 - 5 } & Al Kharj & 217 & 3.53 & .874 \\
\cline { 2 - 5 } & Ad Dilam & 75 & 3.53 & .904 \\
\cline { 2 - 5 } & Total & 325 & 3.54 & .875 \\
\hline Professional Needs & Riyadh & 33 & 3.42 & .697 \\
\cline { 2 - 5 } & Al Kharj & 217 & 3.43 & .607 \\
\cline { 2 - 5 } & Ad Dilam & 75 & 3.34 & .693 \\
\cline { 2 - 5 } & Total & 325 & 3.41 & \\
\hline
\end{tabular}

Table (9) shows apparent variation in arithmetic averages and standard deviations of female students' scores on the counseling needs scale due to the difference in the categories of the place of residence variable. To show 
the significance of the statistical differences between the arithmetic averages, a mono variance analysis was used according to table (10).

Table (10) Analysis of the mono-variance of the effect of the place of residence on the students' scores on the counseling needs scale

\begin{tabular}{|c|c|c|c|c|c|c|}
\hline & Source & $\begin{array}{l}\text { Sum of } \\
\text { squares }\end{array}$ & $\begin{array}{c}\text { Degrees of } \\
\text { Freedom }\end{array}$ & $\begin{array}{l}\text { Average } \\
\text { squares }\end{array}$ & $\begin{array}{c}\text { "F" } \\
\text { Value }\end{array}$ & $\begin{array}{c}\text { Statistical } \\
\text { Significance }\end{array}$ \\
\hline $\begin{array}{l}\text { Psychological } \\
\text { Needs }\end{array}$ & $\begin{array}{l}\text { Between groups } \\
\text { Within groups } \\
\text { Overall }\end{array}$ & $\begin{array}{c}1.558 \\
342.916 \\
344.474\end{array}$ & $\begin{array}{c}2 \\
322 \\
324 \\
\end{array}$ & $\begin{array}{c}.779 \\
1.065\end{array}$ & .731 & .482 \\
\hline Social Needs & $\begin{array}{l}\text { Between groups } \\
\text { Within groups } \\
\text { Overall }\end{array}$ & $\begin{array}{c}.323 \\
230.218 \\
230.540\end{array}$ & $\begin{array}{c}2 \\
322 \\
324 \\
\end{array}$ & $\begin{array}{l}.161 \\
.715\end{array}$ & .226 & .798 \\
\hline Academic Needs & $\begin{array}{l}\text { Between groups } \\
\text { Within groups } \\
\text { Overall }\end{array}$ & $\begin{array}{c}.874 \\
265.501 \\
266.375\end{array}$ & $\begin{array}{c}2 \\
322 \\
324 \\
\end{array}$ & $\begin{array}{l}.437 \\
.825\end{array}$ & .530 & .589 \\
\hline $\begin{array}{l}\text { Professional } \\
\text { Needs }\end{array}$ & $\begin{array}{l}\text { Between groups } \\
\text { Within groups } \\
\text { Overall }\end{array}$ & $\begin{array}{c}.143 \\
247.999 \\
248.142 \\
\end{array}$ & $\begin{array}{c}2 \\
322 \\
324 \\
\end{array}$ & $\begin{array}{l}.072 \\
.770\end{array}$ & .093 & .911 \\
\hline Needs as a whole & $\begin{array}{l}\text { Between groups } \\
\text { Within groups } \\
\text { Overall }\end{array}$ & $\begin{array}{c}.438 \\
155.281 \\
155.718\end{array}$ & $\begin{array}{c}2 \\
322 \\
324 \\
\end{array}$ & $\begin{array}{l}.219 \\
.482\end{array}$ & .454 & .636 \\
\hline
\end{tabular}

Table (10) shows that there are no statistically significant differences at the level of significance $(=0.05)$ due to the location of housing in all areas and in the needs as a whole. This is normal, as the social environments in Ad Dilam, the place of the college, or in the Al Kharj Governorate, which is very close to Ad Dilam, and even in the capital Riyadh, are very similar. There are great similarities to social environments and conditions between these areas. This result is similar to the result of the Al-Samadi and Tahan study, 1996; and Abu Al-Aish study, 2014, which showed that there are no differences due to the variable of the place of residence.

Fourth Question: Are there statistically significant differences between the average female students' grades on the counseling needs scale attributable to the variable of academic specialization?

To answer this question, arithmetic averages and standard deviations for female students' scores were extracted on the counseling needs scale according to the academic specialization variable, and the table below shows that.

Table (11) Arithmetic averages and standard deviations for female students' scores on the scale of counseling needs according to the academic specialization variable

\begin{tabular}{|c|c|c|c|c|}
\hline & Categories & No. & Arithmetic mean & Standard Deviation \\
\hline \multirow[t]{5}{*}{ Psychological Needs } & Mathematics & 43 & 3.63 & 1.149 \\
\hline & Islamic studies & 111 & 3.77 & 1.018 \\
\hline & Economy & 68 & 3.76 & .926 \\
\hline & $\begin{array}{l}\text { Arabic } \\
\text { Language }\end{array}$ & 103 & 3.74 & 1.070 \\
\hline & Total & 325 & 3.74 & 1.031 \\
\hline \multirow[t]{5}{*}{ Social Needs } & Mathematics & 43 & 2.78 & .848 \\
\hline & Islamic studies & 111 & 2.91 & .769 \\
\hline & Economy & 68 & 3.12 & .743 \\
\hline & $\begin{array}{l}\text { Arabic } \\
\text { Language }\end{array}$ & 103 & 3.08 & .958 \\
\hline & Total & 325 & 2.99 & .844 \\
\hline \multirow[t]{5}{*}{ Academic Needs } & Mathematics & 43 & $3: 37$ & 1.024 \\
\hline & Islamic studies & 111 & 3.31 & .869 \\
\hline & Economy & 68 & 3.54 & .865 \\
\hline & $\begin{array}{l}\text { Arabic } \\
\text { Language }\end{array}$ & 103 & $3: 33$ & .922 \\
\hline & Total & 325 & 3:37 & .907 \\
\hline
\end{tabular}




\begin{tabular}{|l|l|c|c|c|}
\hline \multirow{5}{*}{ Professional Needs } & \multicolumn{1}{|c|}{ Categories } & No. & Arithmetic mean & Standard Deviation \\
& Mathematics & 43 & $3: 49$ & .949 \\
\cline { 2 - 5 } & Islamic studies & 111 & 3.56 & .882 \\
\cline { 2 - 5 } & Economy & 68 & 3.60 & .873 \\
\cline { 2 - 5 } & $\begin{array}{l}\text { Arabic } \\
\text { Language }\end{array}$ & 103 & $3: 49$ & .846 \\
\cline { 2 - 5 } & Total & 325 & 3.54 & .875 \\
\hline Needs as a whole & Mathematics & 43 & $3: 32$ & .613 \\
\cline { 2 - 5 } & Islamic studies & 111 & 3.39 & .648 \\
\cline { 2 - 5 } & Economy & 68 & 3.51 & .767 \\
\cline { 2 - 5 } & $\begin{array}{l}\text { Arabic } \\
\text { Language }\end{array}$ & 103 & 3.41 & 3.41 \\
\cline { 2 - 5 } & Total & 325 & 393 \\
\hline
\end{tabular}

Table (11) shows an apparent variation in the arithmetic averages and the standard deviations of female students' scores on the counseling needs scale due to the different categories of the academic specialization variable. To show the significance of the statistical differences between the arithmetic averages, a mono variance analysis was used according to table (12).

Table (12) Analysis of mono-variance of the effect of academic specialization on female students' scores on the counseling needs scale

\begin{tabular}{|c|c|c|c|c|c|c|}
\hline & Source & $\begin{array}{l}\text { Sum of } \\
\text { squares }\end{array}$ & $\begin{array}{c}\text { Degrees of } \\
\text { Freedom }\end{array}$ & $\begin{array}{c}\text { Average } \\
\text { squares }\end{array}$ & $\begin{array}{c}\text { "F" } \\
\text { Value } \\
\end{array}$ & $\begin{array}{c}\text { Statistical } \\
\text { Significance }\end{array}$ \\
\hline Psychological Needs & $\begin{array}{l}\text { Between groups } \\
\text { Within groups } \\
\text { Overall }\end{array}$ & $\begin{array}{c}.653 \\
343.820 \\
344.474 \\
\end{array}$ & $\begin{array}{c}3 \\
321 \\
324 \\
\end{array}$ & $\begin{array}{c}.218 \\
1.071\end{array}$ & .203 & .894 \\
\hline Social Needs & $\begin{array}{l}\text { Between groups } \\
\text { Within groups } \\
\text { Overall }\end{array}$ & $\begin{array}{c}4.706 \\
225.834 \\
230.540 \\
\end{array}$ & $\begin{array}{r}3 \\
321 \\
324 \\
\end{array}$ & $\begin{array}{c}1.569 \\
.704\end{array}$ & 2.230 & .085 \\
\hline Academic Needs & $\begin{array}{l}\text { Between groups } \\
\text { Within groups } \\
\text { Overall }\end{array}$ & $\begin{array}{c}2.460 \\
263.915 \\
266.375 \\
\end{array}$ & $\begin{array}{c}3 \\
321 \\
324 \\
\end{array}$ & $\begin{array}{l}.820 \\
.822\end{array}$ & .997 & .394 \\
\hline Professional Needs & $\begin{array}{l}\text { Between groups } \\
\text { Within groups } \\
\text { Overall }\end{array}$ & $\begin{array}{c}.668 \\
247.474 \\
248.142 \\
\end{array}$ & $\begin{array}{c}3 \\
321 \\
324 \\
\end{array}$ & $\begin{array}{l}.223 \\
.771\end{array}$ & .289 & .833 \\
\hline Needs as a whole & $\begin{array}{l}\text { Between groups } \\
\text { Within groups } \\
\text { Overall }\end{array}$ & $\begin{array}{c}1.035 \\
154.683 \\
155.718\end{array}$ & $\begin{array}{c}3 \\
321 \\
324 \\
\end{array}$ & $\begin{array}{l}.345 \\
.482\end{array}$ & .716 & .543 \\
\hline
\end{tabular}

It is evident from Table (12) that there are no statistically significant differences at the level of significance $(=0.05)$ attributed to academic specialization in all areas and in the needs as a whole. . This result is similar to the result of the Al-Samadi and Tahan study, 1996 and the Ramadan study, 2013; and the Abu Al-Aish study, 2014, which showed that there are no differences attributable to the variable of specialization, and this indicates its importance for students with different specializations.

Fifth Question: Are there statistically significant differences between the average female students' grades on the counseling needs scale attributable to the variable of the academic level?

To answer this question, the mean and standard deviations for female students' grades were extracted from the counseling needs scale depending on the academic level variable, and the table below illustrates that. 
Table (13) Arithmetic averages and standard deviations for female students' scores from the counseling needs scale according to a variable for the academic level

\begin{tabular}{|c|c|c|c|c|}
\hline & Categories & No. & $\begin{array}{c}\text { Arithmetic } \\
\text { mean }\end{array}$ & $\begin{array}{l}\text { Standard } \\
\text { Deviation }\end{array}$ \\
\hline \multirow[t]{5}{*}{ Psychological Needs } & First or Second & 101 & 3.71 & 1.054 \\
\hline & Third or Fourth & 86 & 3.76 & 1.029 \\
\hline & Fifth or Sixth & 126 & 3.74 & 1.050 \\
\hline & Seventh or Eighth & 12 & 3.79 & .710 \\
\hline & Total & 325 & 3.74 & 1.031 \\
\hline \multirow[t]{5}{*}{ Social Needs } & First or Second & 101 & 2.99 & .815 \\
\hline & Third or Fourth & 86 & 3.05 & .923 \\
\hline & Fifth or Sixth & 126 & 2.93 & .837 \\
\hline & Seventh or Eighth & 12 & 3.16 & .532 \\
\hline & Total & 325 & 2.99 & .844 \\
\hline \multirow[t]{5}{*}{ Academic Needs } & First or Second & 101 & $3: 35$ & .942 \\
\hline & Third or Fourth & 86 & $3: 47$ & .887 \\
\hline & Fifth or Sixth & 126 & $3: 29$ & .909 \\
\hline & Seventh or Eighth & 12 & 3.68 & .649 \\
\hline & Total & 325 & $3: 37$ & .907 \\
\hline \multirow[t]{5}{*}{ Professional Needs } & First or Second & 101 & 3.44 & .950 \\
\hline & Third or Fourth & 86 & 3.50 & .837 \\
\hline & Fifth or Sixth & 126 & 3.62 & .816 \\
\hline & Seventh or Eighth & 12 & 3.72 & 1.069 \\
\hline & Total & 325 & 3.54 & .875 \\
\hline \multirow[t]{5}{*}{ Needs as a whole } & First or Second & 101 & $3: 37$ & .723 \\
\hline & Third or Fourth & 86 & $3: 45$ & .731 \\
\hline & Fifth or Sixth & 126 & $3: 40$ & .660 \\
\hline & Seventh or Eighth & 12 & 3.59 & .514 \\
\hline & Total & 325 & 3.41 & .693 \\
\hline
\end{tabular}

Table (13) shows an apparent variation in the arithmetic averages and the standard deviations of female students' scores on the counseling needs scale due to the difference in the categories of the academic level variable. To demonstrate the significance of the statistical differences between the arithmetic averages, a mono variance analysis was used according to table (14).

Table (14) Analysis of mono-variance of the effect of the academic level on female students' scores on the counseling needs scale

\begin{tabular}{|c|c|c|c|c|c|c|}
\hline & Source & $\begin{array}{c}\text { Sum of } \\
\text { squares }\end{array}$ & $\begin{array}{c}\text { Degrees of } \\
\text { Freedom }\end{array}$ & $\begin{array}{l}\text { Average } \\
\text { squares }\end{array}$ & $\begin{array}{c}\text { "F" } \\
\text { Value }\end{array}$ & $\begin{array}{c}\text { Statistical } \\
\text { Significance }\end{array}$ \\
\hline Psychological Needs & $\begin{array}{l}\text { Between groups } \\
\text { Within groups } \\
\text { Overall }\end{array}$ & $\begin{array}{c}.138 \\
344.335 \\
344.474 \\
\end{array}$ & $\begin{array}{c}3 \\
321 \\
324 \\
\end{array}$ & $\begin{array}{c}.046 \\
1.073\end{array}$ & .043 & .988 \\
\hline Social Needs & $\begin{array}{l}\text { Between groups } \\
\text { Within groups } \\
\text { Overall }\end{array}$ & $\begin{array}{c}1.078 \\
229.462 \\
230.540\end{array}$ & $\begin{array}{c}3 \\
321 \\
324 \\
\end{array}$ & $\begin{array}{l}.359 \\
.715\end{array}$ & .503 & .681 \\
\hline Academic Needs & $\begin{array}{l}\text { Between groups } \\
\text { Within groups } \\
\text { Overall }\end{array}$ & $\begin{array}{c}2.906 \\
263.469 \\
266.375 \\
\end{array}$ & $\begin{array}{c}3 \\
321 \\
324 \\
\end{array}$ & $\begin{array}{l}.969 \\
.821\end{array}$ & 1.180 & .317 \\
\hline Professional Needs & $\begin{array}{l}\text { Between groups } \\
\text { Within groups } \\
\text { Overall }\end{array}$ & $\begin{array}{c}2.430 \\
245.712 \\
248.142 \\
\end{array}$ & $\begin{array}{c}3 \\
321 \\
324 \\
\end{array}$ & $\begin{array}{l}.810 \\
.765\end{array}$ & 1.058 & .367 \\
\hline Needs as a whole & $\begin{array}{l}\text { Between groups } \\
\text { Within groups } \\
\text { Overall }\end{array}$ & $\begin{array}{c}.642 \\
155.077 \\
155.718 \\
\end{array}$ & $\begin{array}{c}3 \\
321 \\
324 \\
\end{array}$ & $\begin{array}{l}.214 \\
.483\end{array}$ & .443 & .723 \\
\hline
\end{tabular}

It is evident from Table (13) that there are no statistically significant differences at the level of significance $(=0.05)$ attributed to the academic level in all areas and in the needs as a whole. The researcher believes that the similarity in the needs of students and in various fields is evidence of its importance and necessity for all students with different levels of study. This result is similar to the findings of the study of Tashtoosh, 2012; the 
study of Al-Smadi and Tahan, 1996; the Wainwright et al, 1998 study. They all showed that there were no statistically significant differences attributable to the variable of the school year. However, we found that they differed with the result of the Al-Musharraf study, 2000, which showed a statistically significant difference between students of academic levels. The study showed the suffering of students in the fourth year more than their suffering in First year. The study of Tahan and Abu Eita, 2002, showed that the students of the first level have more suffering than other levels. The study of Nuri and Yahya, 2008, showed significant differences between the students in counseling needs for the benefit of students in the fourth stage.

In light of the previous results, the researcher reached several recommendations, the most important of which are:

- Taking advantage of the study results to develop counseling programs in the college and build them on scientific rules stemming from the real needs that have been reached.

- Paying attention to activating the role of the counseling unit in the College of Education in Ad Dilam.

- The need to appoint a dedicated and full-time Counsellor to follow up the counseling cases in the college.

- Assigning college instructors to use a portion of the lecture time to be acquainted with the needs of female students and work on following them up with the counseling unit at the university.

- Holding seminars, meetings and counseling programs continuously in the college to educate students about the importance of university counseling, and to introduce its services and its role in achieving and meeting the counseling needs.

- The necessity of providing an integrated counseling center that includes various counseling areas (psychological, social, academic, professional ... etc.) in the university administration to help female students face their problems of all kinds.

- Working to activate the career counseling unit in the college by introducing students to the required professions in the labor market and how to introduce themselves to the labor market by teaching them how to do a successful job interview and how to write a $\mathrm{CV}$.

\section{Arabic References}

- The Holy Quran.

- Abu Al-Aish, Haya (2014). The Counseling Needs of Female Students of the College of Education at the University of Hail. Arab Journal for the Development of Excellence, 5 (9).

- Al-Mishrif. Farida Abdel Wahab (2000). Sana'a University Students Problems and their Counseling Needs. Educational Journal, 45 (14), Kuwait University, Scientific Publishing Council.

- Al-Barakat, Ali; Al-Hakmani, Nasser (2014). Counseling Needs for Students of Private Universities in the Sultanate of Oman. Journal of the Federation of Arab Universities for Education and Psychology, 12 (3).

- Jubouri, Haytham (2011). Counseling Needs for Students of the Faculty of Physical Education - University of Babylon. Journal of Physical Education Sciences 4 (2).

- Al-Saqiyyah, Al-Jawhara (2013). The Counseling Needs for Students of the Faculty of Education at Princess Nora Bint Abdul Rahman University and their Correlation to the Educational Level, Journal of Educational and Psychological Sciences, 14 (1).

- Al-Smadi, Ahmad; Al-Tahhan, Muhammad (1996). Counseling Needs for Emirates University Students. Yarmouk Research Journal, Humanities and Social Sciences Series, 13 (2), 21-35.

- Al-Tahhan, Muhammad; Abu Eita, Siham (2002). Counseling Needs for the Hashemite University Students. Journal of Educational Sciences Studies, Issue 1, Volume 29, University of Jordan.

- Toshtoush, Rami (2012). Counseling Needs for Preparatory Year Students in the Qaseem University. Journal of Gulf and Arab Studies, 38 (146), 279-320.

- Rizk, Amina (2008), The Problems of Secondary School Students and their Counseling Needs (A Field Study on a Sample of Students in the Governorate of Damascus). Damascus University Journal, 24 (2).

- Ramadan, Hadi; Sarhan, Jinan (2016), Counseling Needs and Academic Ambition of University Students Living and Not Living in Internal Departments, Al-Ustaz Magazine, Issue 218, second volume, 233-254.

- $\quad$ Ramadan, Hadi (2013), Counseling Needs of Students of the College of Education, Research Journal of the College of Basic Education, 12 (3).

- Nuri, Ahmad; Yahya, Muhammad (2008), Counseling Needs (Psychological - Social - Academic) Among Mosul University Students, Journal of Education and Science, 15 (3). 


\section{Foreign References}

- Egbochuku, E. \& Akpan 2008. An Assessment of Counseling Needs of Nigerian University Graduate Students. European Journal of Economics, Finance and Administrative Science, 11. 66-73.

- Collins, M. \& Pieters, L. (2007). Critical Incident Analysis Based Learning. An approach to training for active racial and cultural awareness, Journal of Counseling and Development, 85, 14-23.

- Giovazolias. T., Leontopouou, S. \& Triliva, S. (2010). Assessment of Greek University Students' Counseling Needs and Attitudes: An Exploratory Study. International Journal of Adv Counseling, 32, 101116.

- Guneri, Y., Ayd, G. \& Shovholt, T. (2003). Counseling Needs of Students and Evaluation of Counseling Services at a Large Urban University in Turkey. International Journal for Advanced of Counseling, 25(1), 53-63.

- Grenchik. D. O'Connor. E. \& Postelli, G. (1999) "Effective Motivation through Meeting Students' Needs" 1. Master degree thesis, University of Saint Xavier.

- Gilbert, J. B. Probst et., al (1997): Organization of management les Edition of organization, Paris.

- Thompson, C. L. \& Rudolph, L. B (1992): Counseling Children, 3 ed, Pacific Grove, CA, Brocksl, Gole. p44.

- Wainwrihgt, P.; Pharoah, G.; Surtees, P. (1998). A Follow-up Study for New Users of University Counseling Service. British Journal of Counseling \& Counseling, 26 (2), p 255. 